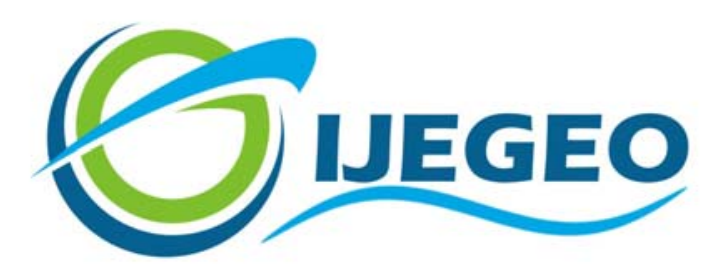

International Journal of Environment and Geoinformatics (IJEGEO) is an international, multidisciplinary, peer reviewed, open access journal.

\title{
Winter Crop Growth Monitoring using Multi-Temporal NDVI Profiles in Kapadvanj Taluka, Gujarat State
}

\author{
Disha H. MEHTA., Shital H. SHUKLA., Manik H. KALUBARME
}

\author{
Chief in Editor \\ Prof. Dr. Cem Gazioğlu \\ Co-Editors \\ Prof. Dr. Dursun Zafer Şeker, Prof. Dr. Şinasi Kaya, \\ Prof. Dr. Ayşegül Tanık and Assist. Prof. Dr. Volkan Demir
}

Editorial Committee (March 2021)

Assoc. Prof. Dr. Abdullah Aksu (TR), Assit. Prof. Dr. Uğur Algancı (TR), Prof. Dr. Bedri Alpar (TR), Assoc. Prof. Dr. Aslı Aslan (US), Prof. Dr. Levent Bat (TR), Prof. Dr. Paul Bates (UK), İrşad Bayırhan (TR), Prof. Dr. Bülent Bayram (TR), Prof. Dr. Luis M. Botana (ES), Prof. Dr. Nuray Çağlar (TR), Prof. Dr. Sukanta Dash (IN), Dr. Soofia T. Elias (UK), Prof. Dr. A. Evren Erginal (TR), Assoc. Prof. Dr. Cüneyt Erenoğlu (TR), Dr. Dieter Fritsch (DE), Prof. Dr. Çiğdem Göksel (TR), Prof.Dr. Lena Halounova (CZ), Prof. Dr. Manik Kalubarme (IN), Dr. Hakan Kaya (TR), Assist. Prof. Dr. Serkan Kükrer (TR), Assoc. Prof. Dr. Maged Marghany (MY), Prof. Dr. Michael Meadows (ZA), Prof. Dr. Nebiye Musaoğlu (TR), Prof. Dr. Masafumi Nakagawa (JP), Prof. Dr. Hasan Özdemir (TR), Prof. Dr. Chryssy Potsiou (GR), Prof. Dr. Erol Sarı (TR), Prof. Dr. Maria Paradiso (IT), Prof. Dr. Petros Patias (GR), Prof. Dr. Elif Sertel (TR), Prof. Dr. Nüket Sivri (TR), Prof. Dr. Füsun Balık Şanlı (TR), Prof. Dr. Uğur Şanlı (TR), Duygu Ülker (TR), Prof. Dr. Seyfettin Taş (TR), Assoc. Prof. Dr. Ömer Suat Taşkın (TR), Assist. Prof. Dr. Tuba Ünsal (TR), Dr. Manousos Valyrakis (UK), Dr. İnese Varna (LV), Dr. Petra Visser (NL), Prof. Dr. Selma Ünlü (TR), Assoc. Prof. Dr. Oral Yağcı (TR), Prof. Dr. Murat Yakar (TR), Assoc. Prof. Dr. İ. Noyan Yılmaz (AU); Assit. Prof. Dr. Sibel Zeki (TR)

Abstracting and Indexing: TR DIZIN, DOAJ, Index Copernicus, OAJI, Scientific Indexing Services, International Scientific Indexing, Journal Factor, Google Scholar, Ulrich's Periodicals Directory, WorldCat, DRJI, ResearchBib, SOBIAD 


\title{
Research Article
}

\section{Winter Crop Growth Monitoring using Multi-Temporal NDVI Profiles in Kapadvanj Taluka, Gujarat State}

\author{
Disha H. Mehta ${ }^{1, *}$ iD , Shital H. Shukla1 ${ }^{1}$, Manik H. Kalubarme ${ }^{2}$ iD \\ ${ }^{1}$ Department of Earth Science, School of Sciences, Gujarat University, Ahmedabad, India \\ ${ }^{2}$ Bhaskarcharya Institute for Space Applications and Geo-Informatics (BISAG), Department of Science and Technology, Government of Gujarat, \\ Gandhinagar, India
}

How to cite: Mehta et al., (2021). Winter Crop Growth Monitoring using Multi-Temporal NDVI Profiles in Kapadvanj Taluka, Gujarat State. International Journal of Environment and Geoinformatics (IJEGEO), 8(1):033-038. doi: 10.30897/ijegeo.773860

\begin{abstract}
In the present study on winter crop growth monitoring in different villages in Kapadvanj Taluka of Kheda district was carried out using multi-temporal Sentinel-2 multi-spectral data (spatial resolution 10-m). Multi-temporal Sentinel-2 data covering study area for the winter crop period from November-2018 to March-2019 was downloaded from https://earthexplorer.usgs.gov/. The major objective of this study was to monitor site-specific crop growth in different villages of Kapadvanj Taluka by generating Normalized Difference Vegetation Index (NDVI) profiles of major winter crops. The spectral behavior of wheat, potato, bajara and castor crops during active growth stages was studied and it was observed that the spectral response of wheat and potato crops have quite distinct spectral behavior. However, castor and bajara crops do not show distinct spectral behavior. In this study, from the NDVI profiles of different crops it was observed that very distinct growth stages like early growth stage to flag leaf emergence which correspondence to rising of NDVI, followed by flag leaf emergence to flowering and grain filling stages which corresponds to maximum NDVI and finally physiological maturity stages corresponding to declining of NDVI of all the winter crops.
\end{abstract}

Keywords: Sentinel-2 Multi-spectral data; Spectral behaviour; NDVI; winter crops

Introduction

Indian agriculture plays very important role in the economy of the country which is influenced by year-toyear variability in monsoon affecting the crop production. The spatio-temporal information about crop growth and its condition is important for monitoring crop progression during the growing season which provides information necessary for efficient crop management. Remote sensing data can be effectively used for providing spatial and temporal information on crop growth and its condition and also for generating crop phenology during growing season. Vegetation indices (VI) computed from satellite images gives an indication of the presence of vegetation and its health. Several studies on remote sensing applications have proved that VI can be used effectively in crop monitoring as well as in characterizing the vegetation with crop phenology. Time series profiles of VI derived from satellite data are potential tools to interpret the dynamics and phenological development of vegetation in different areas.

\section{Crop Phenology Detection using Remote Sensing}

Vegetation indices computed from satellite images gives an indication of the presence of vegetation and its health. Studies on remote sensing applications have proved that vegetation indices can be used effectively in crop monitoring as well as in characterizing the vegetation with phenology. Time series profiles of vegetation indices derived from satellite data are potential tools to interpret the dynamics and phenological development of vegetation in different areas (Patel and Oza, 2014). NDVI has been recognized for its ability to monitor crops and as estimator of crop yields since early 1980s (Tucker et al., 1980; Groten, 1993; Quarmby et al., 1993; Doraiswamy and Cook, 1995; Lewis et al., 1998; Boken and Shaykewich, 2002; Kaya et al., 2015; Vaghela et al., 2018; Esetli et al., 2018). Maximum leaf area is achieved 10-15 days before anthesis (flowering stage). Labus et al., (2002) have found good relationship between wheat yield and NDVI during the latter part of the growing season, prior to harvest, at the regional scale. Multi-date MODIS data for previous five years provided a-priori information on crop presence / absence over the previous five crop seasons (Rajak et al., 2016). The methodology was to extract key elements of crop growth cycle (i.e. number of crops per year and their planting - peak harvesting dates) by analyzing MODIS-NDVI data series of one agricultural year (from June 2012 to May 2013) over Gujarat.

\section{Materials and Methods Study Area}

This research was conducted in Kapadvanj taluka which is situated at 23001'12" $\mathrm{N}$ and 73004'12" E located in Kheda districts in Gujarat State. Kapadvanj Taluka has 
geographical area of 19 sq. kilometer. Population of Kapadvanj is 49,308. Kapadvanj usually experiences a semi-arid climate. The temperatures shoot up to 45-47 degree Celsius especially in the month of May. Hot winds blow over the region known as "Loo". Rainy season starts from July and ends in September. Rainfall is between $750-800 \mathrm{~mm}$. The major crops grown during Rabi season (winter) are wheat, potato, castor, bajara and Mustard. In winters temperatures fall to 8-9 degree Celsius. Mild climate causes pleasant weather during the season. The location map of the study area of Kapadvanj Taluka in Kheda district is given in Figure 1.
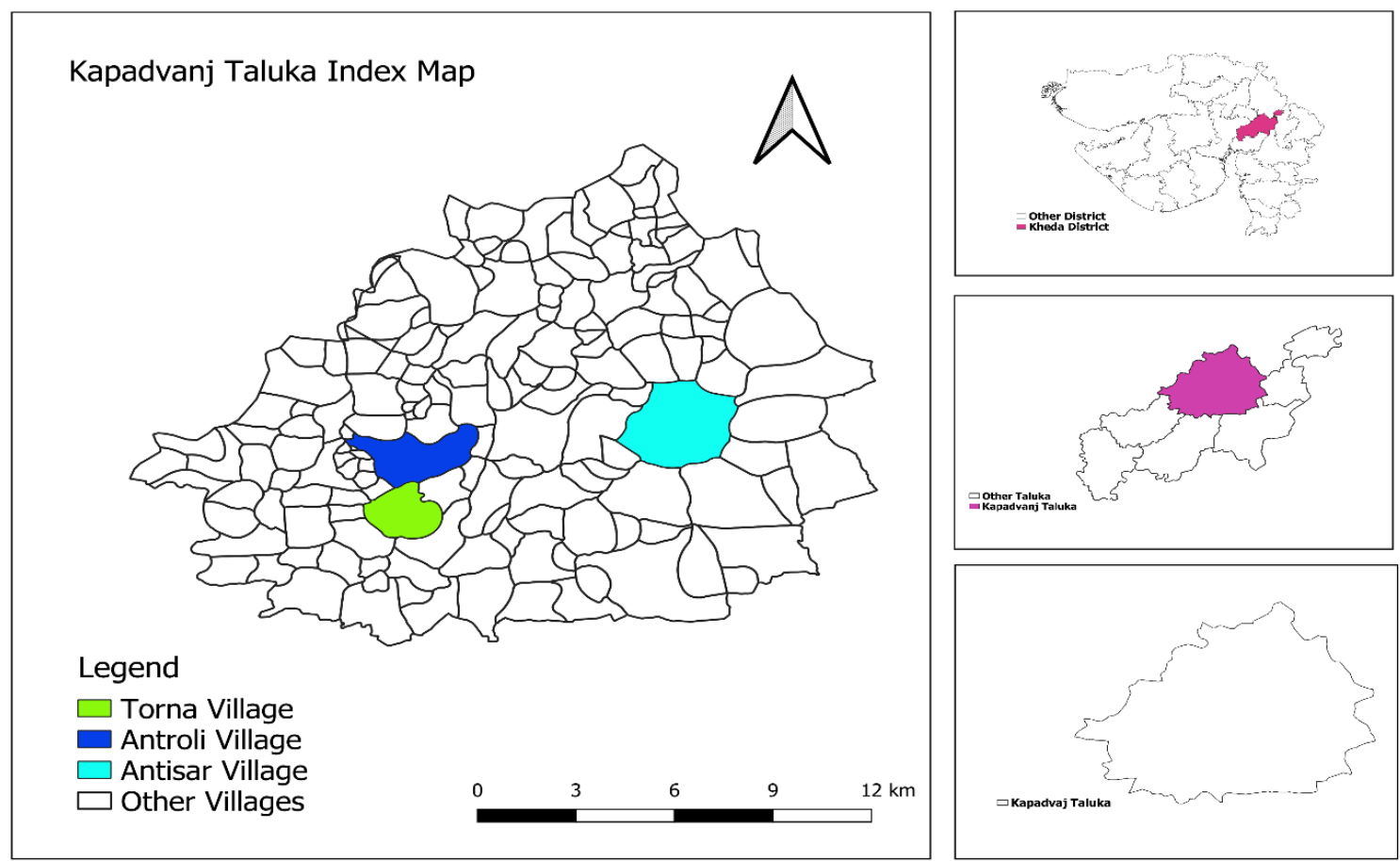

Figure-1: Location map of the Kapadvanj Taluka in Kheda district.

Table-1: Details of Sentinel-2 MSI Data acquired for Rabi Season (2018-19)

\begin{tabular}{|c|c|c|c|c|}
\hline Sr. No. & Satellite / Sensor & Spatial Resolution (m) & Bands Used & Acquisition Date \\
\hline 1. & Sentinel-2 MSI & 10 & $\begin{array}{c}\text { Blue (2), Green (3), Red (4), } \\
\text { NIR (8) }\end{array}$ & $29-11-2018$ \\
\hline 2. & Sentinel-2 MSI & 10 & $\begin{array}{c}\text { Blue (2), Green (3), Red (4), } \\
\text { NIR (8) }\end{array}$ & $29-12-2018$ \\
\hline 3. & Sentinel-2 MSI & 10 & $\begin{array}{c}\text { Blue (2), Green (3), Red (4), } \\
\text { NIR (8) }\end{array}$ & 13-01-2019 \\
\hline 4. & Sentinel-2 MSI & 10 & $\begin{array}{c}\text { Blue (2), Green (3), Red (4), } \\
\text { NIR (8) }\end{array}$ & 28-01-2019 \\
\hline 5. & Sentinel-2 MSI & 10 & $\begin{array}{c}\text { Blue (2), Green (3), Red (4), } \\
\text { NIR (8) }\end{array}$ & 22-02-2019 \\
\hline 6 & Sentinel-2 MSI & 10 & $\begin{array}{c}\text { Blue (2), Green (3), Red (4), } \\
\text { NIR (8) }\end{array}$ & 24-03-2019 \\
\hline
\end{tabular}

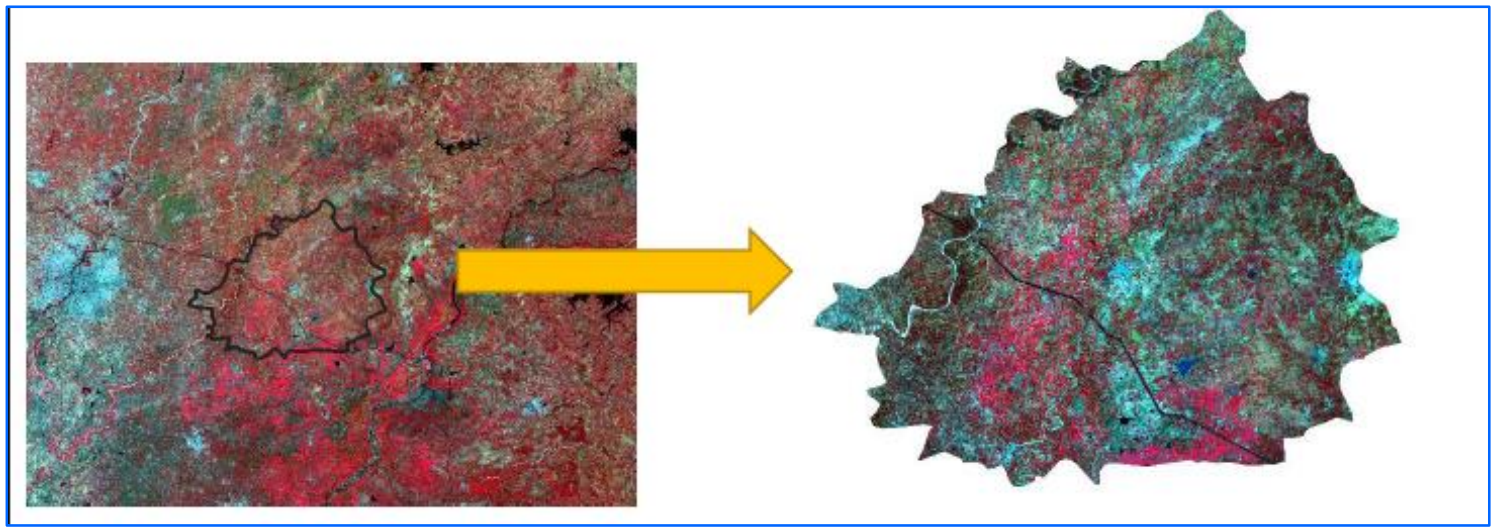

Figure 2: Sentinel-2 multi-spectral image covering part of Kapadvanj Taluka 


\section{Methodology \\ Satellite Data}

In this study, multi-temporal Sentinel-2 multispectraldigital data (spatial resolution 10m) of Rabi season (winter season) from November-2018 to March2019, a total number of 6-date data covering Kapadvanj taluka was downloaded from earthexplorer.usgs.gov/. The details of Sentinel-2 multi-spectraldigital data acquired are given in Table-1. One of the Sentinel-2 data with Kapadvanj Taluka boundary is given in Figure-2.

\section{Field Data Collection}

Ground Truth (GT) data on winter crops grown in different villages of Kapadvanj Taluka was collected at multiple locations coinciding with different growth stagesof winter crops. Large homogeneous sites of wheat and mustard crops with different density classes were identified using the Sentinel-2 False Colour Composite (FCC). The field observations like growth stage and vigour,crop density, size of the field, etc. were recorded for selected sites. The GPS measurements of selected sites along with field photographs were recorded. Some of the field photographs of wheat and mustard crops are given in Figure-3.

\section{Remote Sensing Satellite Data Analysis}

The Sentinel-2 multi-spectral and multi-temporal data of winter crop growing season covering study area was analyzed using following major steps:

- Multi-date data preparation and georeferencing, ii) Administrative boundary superimposing, iii) Extraction of area of interest, iv) Superimposing GPS locations of different crop sites collected during GT data collection on the registered satellite digital data, v) Identification of different crops on the satellite data and generation of histograms vi) Generation of Normalized Difference Vegetation Index (NDVI) images and NDVI profiles of different crops. The multi-date Sentinel-2 multi-spectral images used in this study are given in Figure-4.
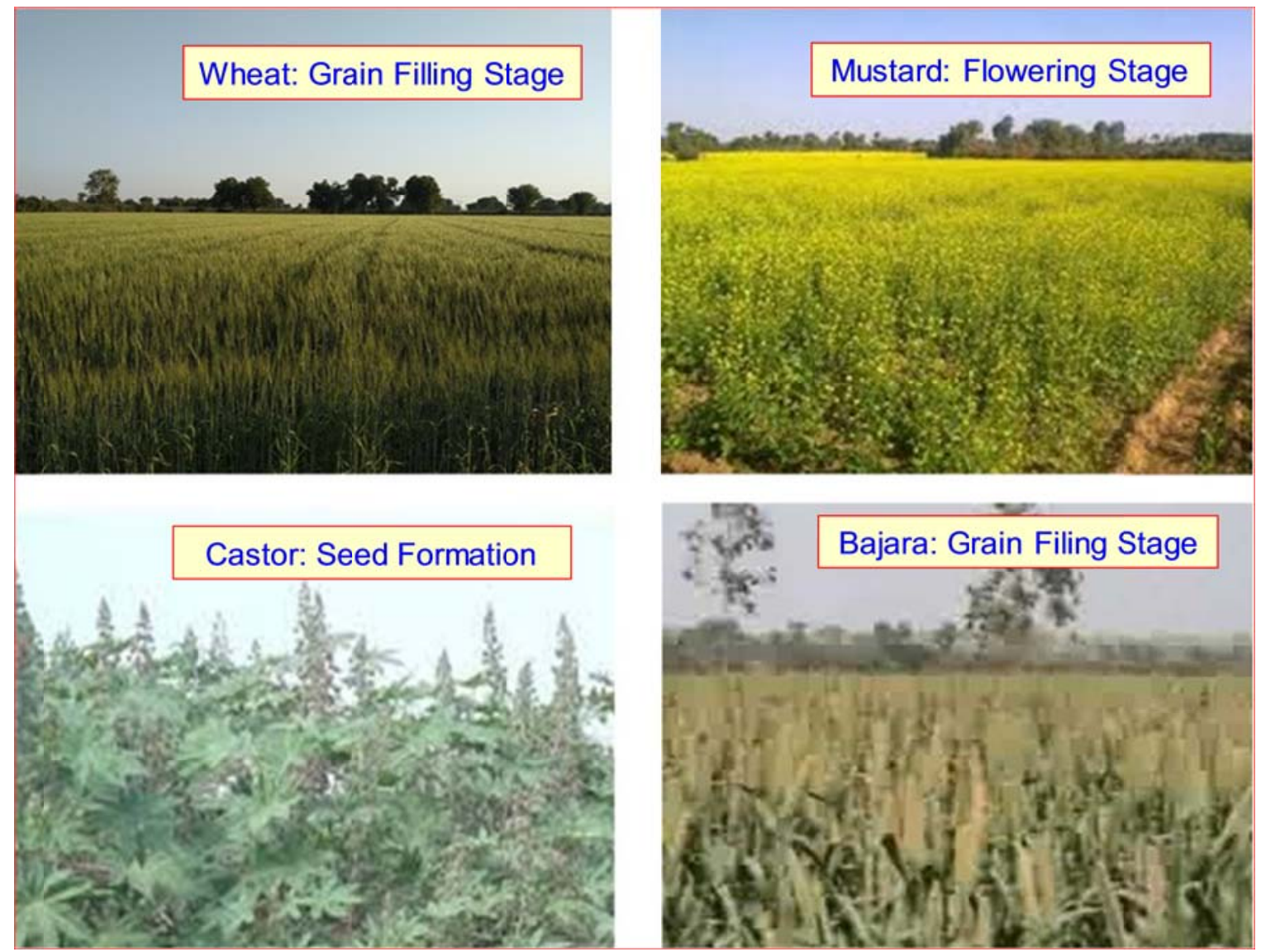

Figure 3: Field Photographs of Major Winter crops in Kapadvanj Taluka.

\section{Results and Discussion \\ Spectral Behavior of different Rabi Crops}

The histograms of digital numbers of different Rabi crop sites identified based on field data at different locations in the selected villages were generated using multi-date Sentnel-2 data (Şekertekin et al., 2018). The mean values in each spectral band for 4-Rabi, crops namely, potato, wheat, Castor and bajara were plotted for 28-Jan-and 24March-2019 where the spectral differences of these crops were significantly different (Figure-5). During these two dates these major crops were at active growth stages of flowering and grain filling. The difference in sowing dates of these winter crops results in different 
phenological stages which results in different spectral response of these crops. It was observed from the spectral response of wheat and potato crops have quite distinct spectral behavior. However, castor and bajara crops do not show distinct spectral behavior on both these dates. Therefore, using Remote Sensing digital

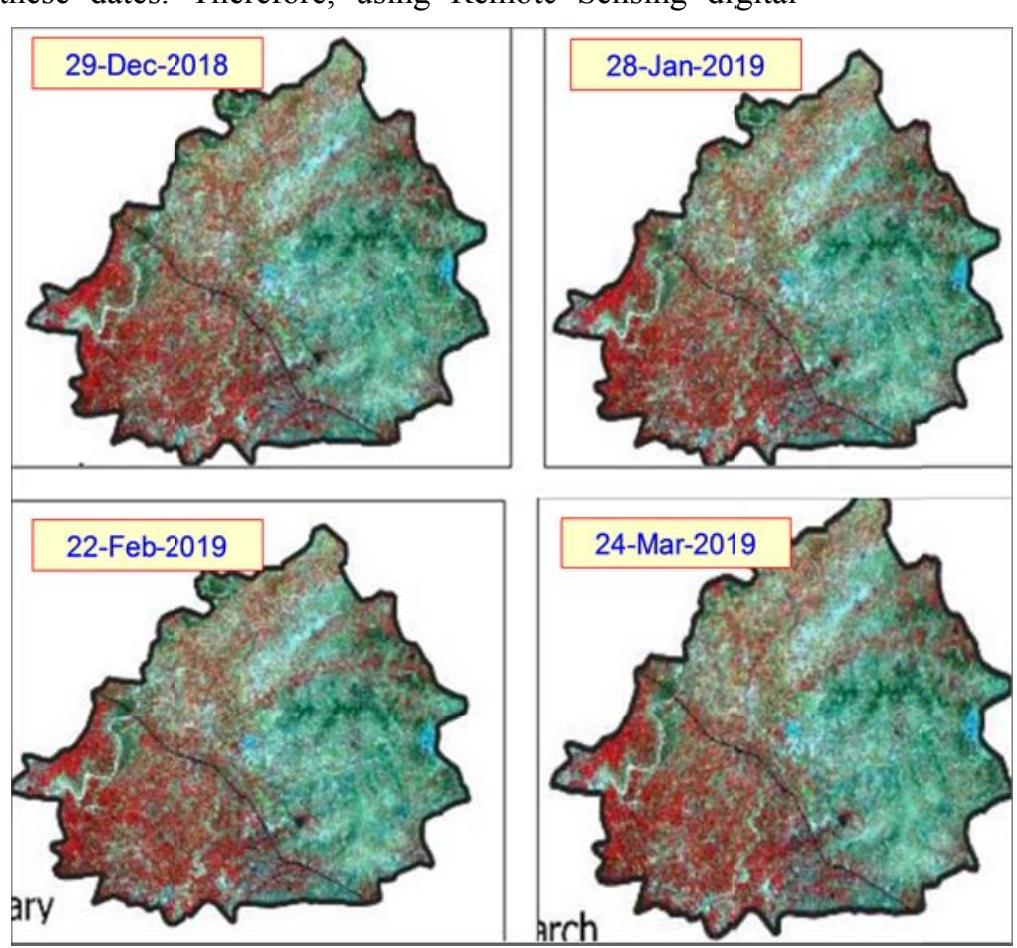

data of these two dates' wheat and potato can uniquely be distinguished and classified; however, it may be difficult to distinguish bajara and castor separately. But the spectral behavior these two crops are quite distinct from wheat and potato.

Figure 4: Multi-date Sentinel-2 multi-spectral images covering part of Kapadvanj .
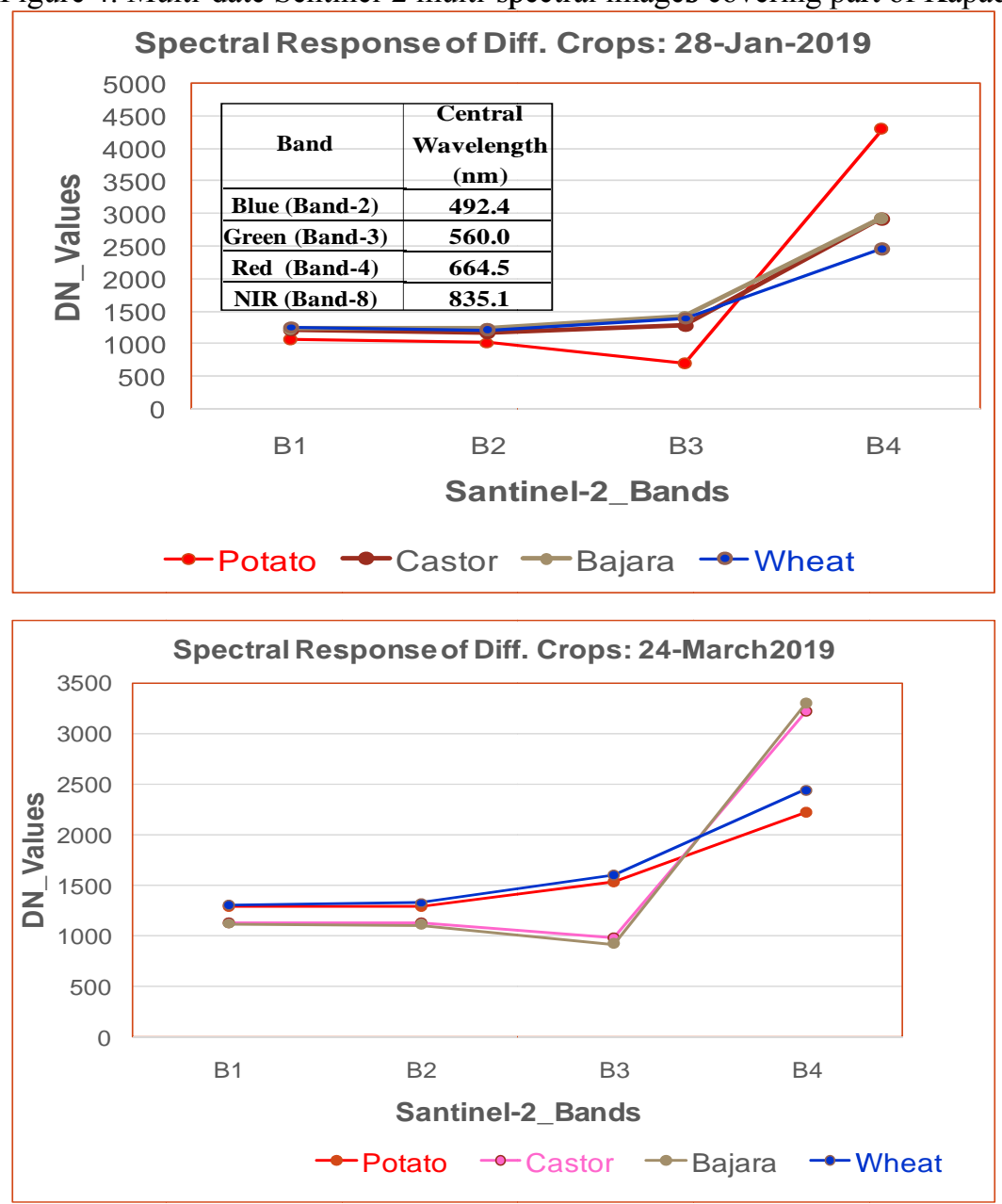

Figure 5: Spectral response of Different Rabi crops using Sentinel-2 multi-spectral data. 


\section{Multi-temporal NDVI Generation}

Various vegetation indices have been developed for follows (Rouse et al. 1973):

qualitative and quantitative assessment of crop growth and vigour using multi-spectral data. The vegetation indices based on the Visible and Near Infra-Red (VNIR) region such as Normalized Difference Vegetation Index (NDVI) (Tucker, Where, 1979) are highly related to biophysical variables such as leaf area index (LAI) and normalized photosynthetically active radiation (NPAR) (Baret and Guyot, 1991). Normalized Difference Vegetation Index (NDVI) is one of the most widely used vegetation indices whose values range from Multi-date NDVI images were generated from the Sentinel-2 +1.0 to -1.0 . NDVI profiles can be generated over time to multi-spectral data from sowing to maturity stages of these study the crop growing conditions throughout the cropping winter crops (Figure-6).
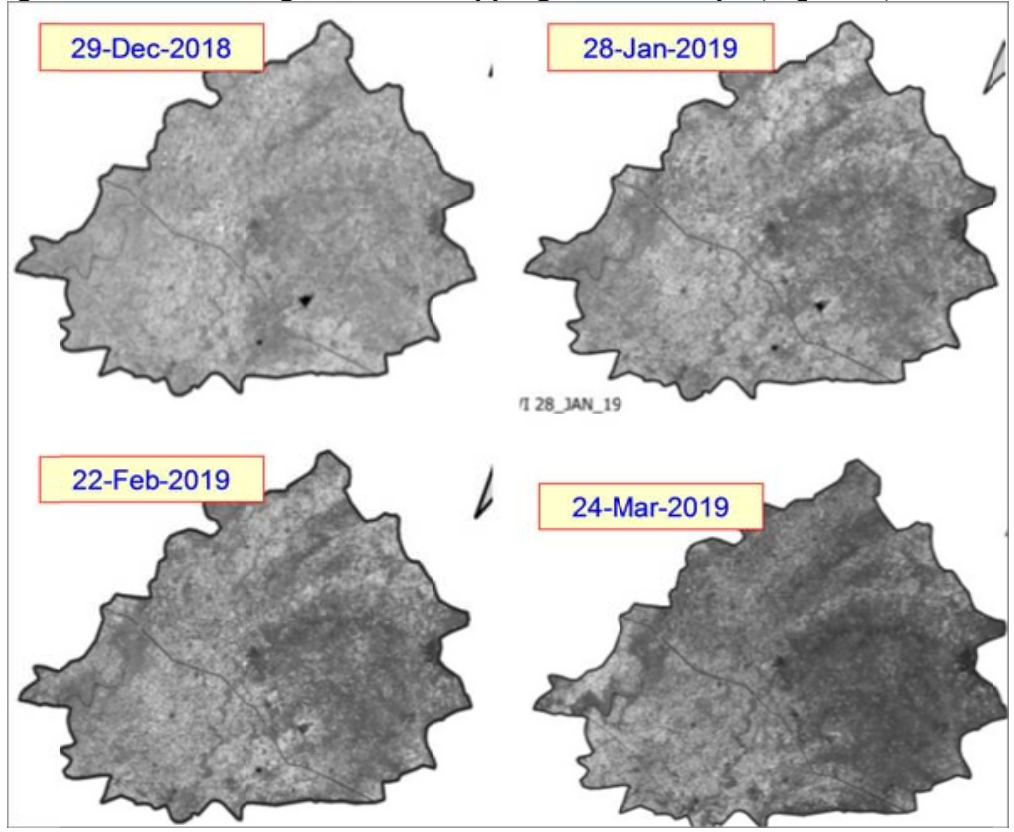

Figure 6: Multi-date NDVI images generated using Sentinel-2 covering Kapadvanj

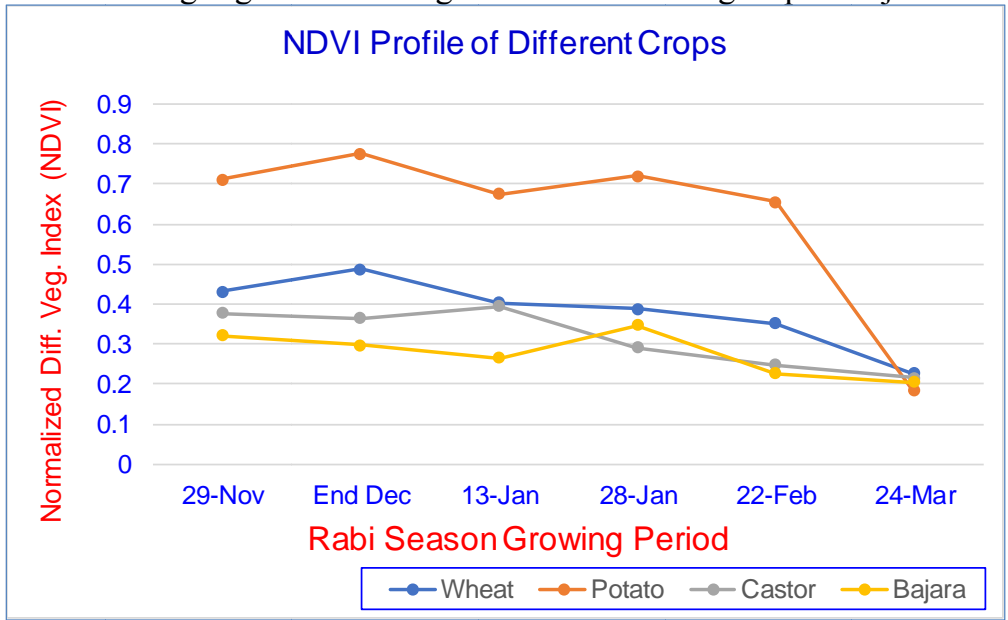

Figure 7: Multi-temporal NDVI profiles of different Rabi Crops using Sentinel-2 data .

The GPS measurements were taken in crop fields at different locations and crops were identified on the satellite images using these GPS measurements taken in different fields of wheat, potato, bajara and castor crops. The histograms of digital numbers of crop sites were generated using the Multi-temporal NDVI images. The multi-temporal NDVI profiles of these major Rabi crops grown in different villages of Kapadvanj Taluka were generated using multi-date Sentinel-2 multispectral data (Figure-7). The NDVI growth profiles of these winter crops indicate the temporal variations during different growth stages of these four crops. The maximum temporal variations can be observed during early growth stages to flowering and grain filling stages. These differences are mainly because of differences in sowing dates resulting in different phonological stages. 
In this study, from the NDVI profiles of different crops it was observed that very distinct growth stages like early growth stage to flag leaf emergence which correspondence to rising of NDVI, followed by flag leaf emergence to flowering and grain filling stages which corresponds to maximum NDVI and finally physiological maturity stages corresponding to declining of NDVI of all the winter crops, were observed. NDVI profiles of these four winter crops were studied for identifying the different growth stages where maximum variations in NDVI profiles can be observed which can help to better crop separability using the spectral data from Remote sensing satellites.

\section{Conclusion}

The site-specific winter crop growth monitoring in different villages in Kapadvanj Taluka of Kheda district was carried out using multi-temporal Sentinel-2 multispectral data. The difference in sowing dates of winter crops results in different phrenological stages which results in considerable difference in spectral signatures. The spectral response of wheat and potato crops have quite distinct however, castor and bajara crops do not show distinct spectral behavior. But the spectral behavior these two crops are quite distinct from wheat and potato. The results indicate that, using Remote Sensing digital data of active growth stages wheat and potato can uniquely be distinguished and classified; however, it may be difficult to distinguish bajara and castor separately. Normalized Difference Vegetation Index (NDVI) growth profiles of major winter crops like wheat, potato, bajara and castor were generated using multi-temporal Sentinel-2 multi-spectral data. The NDVI growth profiles winter crops indicate the temporal variations during different growth stages of these crops and the maximum temporal variations can be seen during early growth stages to flowering and grain filling stages.

\section{Acknowledgements}

The authors express their sincere thanks to Director, Bhaskaracharya Institute for Space Applications and Geo-informatics (BISAG), Department of Science and Technology, Government of Gujarat, Gandhinagar 382007, for his keen interest and encouragement in carrying out this study. The authors are also very much thankful to Head of Department, Department of Earth Science, School of Sciences, Gujarat University, Ahmedabad-380009.

\section{References}

Boken, V., Shaykewich, CF. (2002). Improving an Operational Wheat Yield Model using Phenological Phase-based Normalized Difference Vegetation Index, International Journal of Remote Sensing, 23(20):4155-4168

Brdjanovic, D., Meijer, S. C., Lopez-Vazquez, C. M., Hooijmans, C. M., van Loosdrecht, M. C. (Eds.). (2015). Applications of activated sludge models. Iwa Publishing.
Doraiswamy, P.C., Cook, P W. (1995). Spring Wheat Yield Assessment Using NOAA AVHRR Data, Canadian Journal of Remote Sensing, 21(1), 43-51

Esetlili, M., Bektas Balcik, F., Balik Sanli, F., Kalkan, K., Ustuner, M., Goksel, C., Gazioğlu, C., Kurucu, Y. (2018). Comparison of Object and Pixel-Based Classifications For Mapping Crops Using Rapideye Imagery: A Case Study Of Menemen Plain, Turkey. International Journal of Environment and Geoinformatics, 5(2), 231-243. DOI: 10.30897/ijegeo.442002.

Groten S.M.E. (1993). NDVI- monitoring and early yield assessment of Burkina Faso, International Journal of Remote Sensing, 14(8), 1495-151.

https://earthexplorer.usgs.gov/download/options/12267/ LE70970682017017ASA00/

Kaya, S., Gazioğlu, C., Sertel, E., Şeker, D.Z., and Alganc1, U. (2015). Rapid determination of land use/cover changes using data fusion. The 36th Asian Conference on Remote Sensing "Fostering Resilient Growth in Asia", Metro Manila, Filipinler, 19-23 October 2015.

Labus, M.P., Nielsen, G.A., Lawrence, R.L., Engel, R., Long, D.S. (2002). Wheat Yield Estimates using Multi-temporal NDVI Satellite Imagery, International Journal of Remote Sensing, 23(20): 4169-4180

Patel, J. H., Oza, M.P. (2014). Deriving Crop Calendar using NDVI Time-Series. The International Archives of the Photogrammetry, Remote Sensing and Spatial Information Sciences, Volume XL-8, 2014 ISPRS Technical Commission VIII Symposium, 09 - 12 December 2014, Hyderabad, India.

Quarmby, N.A., Milnes, M., Hindle, T. L., Silleos, N. (1993). The use of multi-temporal NDVI measurements from AVHRR data for crop yield estimation and prediction, International Journal of Remote Sensing, 14(2), 199-210

Rajak, D., Ram, J., Rajesh K., Ray, SS. (2016). Early estimation of crop sown area by integrating multisource data. Journal of Geomatics, Vol. 10 No. 1, April 2016, pp. $80-88$.

Şekertekin, A., Marangoz, AM., Abdikan, S. (2018). Soil moisture mapping using Sentinel-1A synthetic aperture radar data, International Journal of Environment and Geoinformatics, 5 (2), 178-188, 10.30897/ijegeo. 425606.

Tucker C.J., Elgin J.H., McMurtrey. (1980). Relationship of red and photographic infrared spectral data to alfalfa biomass, canopy cover and drought stress, International Journal of Remote Sensing, 1(1):(in press)

Vaghela, B., Parmar, M., Solanki, H., Kansara, B., Prajapati, S., Kalubarme, M. (2018). Multi Criteria Decision Making (MCDM) Approach for Mangrove Health Assessment using Geo-informatics Technology, International Journal of Environment and Geoinformatics, 5(2), 114-131. DOI: 10.30897/ijegeo.412511. 